\title{
Influence of lamb rennet paste on the lipolytic and sensory profile of Murcia al Vino cheese
}

\author{
E. Ferrandini, ${ }^{\star}$ M. Castillo,† M. de Renobales,‡ M. D. Virto,‡ M. D. Garrido, ${ }^{\star}$ S. Rovira, ${ }^{\star}$ and M. B. López ${ }^{\star 1}$ \\ *Department of Food Science and Technology, Veterinary Faculty, University of Murcia, Campus de Espinardo, E- 30071 Murcia, Spain \\ †Department of Animal and Food Science, Universidad Autónoma de Barcelona, Edificio V, Campus de Bellaterra, 08193 Barcelona, Spain \\ ‡Department of Biochemistry and Molecular Biology, University of País Vasco, Apartado 450, E-01080 Vitoria, Spain
}

\begin{abstract}
The influence of lamb rennet paste $(71.1 \%$ chymosin, 177 international milk-clotting units $/ \mathrm{mL}, 4.57 \mathrm{U} / \mathrm{g}$ of lipase activity) during the ripening of Murcia al Vino goat cheese was studied. The aim of this study was to improve the knowledge of the effect of lamb rennet paste on the lipolytic patterns in this type of cheese by reference to the evolution of total and free fatty acids. A sensory analysis was carried out to compare cheeses made with commercial and paste rennet. The rennet paste showed higher lipolytic activity, enhancing the production of short-chain free fatty acids. In addition, the cheese produced with lamb rennet paste had a slightly more bitter and piquant taste, making it an attractive commercial alternative that can be used to develop new varieties of goat cheese.
\end{abstract}

Key words: rennet paste, fatty acid, goat cheese, sensory

\section{INTRODUCTION}

Liquid or powdered calf rennets are more commonly used as coagulants in cheese industries than paste rennets in an attempt to standardize the cheesemaking process. Commercial liquid rennets do not have lipolytic enzymes, whereas paste rennets contain pregastric esterase, the presence of which is due to the suckling action of the lambs, which stimulates the enzyme's secretion at the base of the tongue before it passes along the abomasa with the ingested milk. Slight differences can be observed in the enzyme's specificity among different animal species, which translates into small differences in the current cheesy taste (Collins et al., 2003). The literature consulted shows that, despite the increased commercial interest in lamb rennet paste, very few

Received July 15, 2011.

Accepted January 20, 2012.

${ }^{1}$ Corresponding author: mbelen@um.es authors have studied its suitability as an alternative in cheese manufacture, as the lipases contained in rennet paste markedly influence the final characteristics of a cheese (Addis et al., 2008).

Several studies on cheeses made with lamb rennet paste discussed the influence on fat hydrolysis patterns during ripening and the involvement of secondary products in the perception of characteristic flavors and tastes (Virto et al., 2003). Some authors (Addis et al., 2008) affirm that the lamb rennet paste obtained from the abomasa of animals fed with milk and killed immediately after its ingestion contains significantly higher levels of lipase activity than those obtained from empty stomachs. When the abomasa are from weaned lambs, pregastric lipase activity may decrease, whereas gastric and microbial lipase activity increases (Addis et al., 2008). Such observations demonstrate the complexity of the enzymatic systems observed in paste rennet in comparison with that of liquid and powdered calf rennet.

Harboe (1994) highlighted the importance of using rennet paste from ruminants, as it generates lipolytic processes that impart excellent cheese tastes, probably due to the presence of other enzymes than pregastric lipase and coagulant enzymes currently presented in the rest of paste rennets. The FFA released during lipolysis, together with the volatile compounds and proteolysis products, contribute to the taste of cheese (McSweeney, 2004), whereas short-chain FA, especially butyric acid, play an important role in the organoleptic properties of cheeses made with lamb rennet paste. The Greek and Italian markets prefer the strongly flavored cheeses elaborated by crushing the mucosa of sheep or goat stomachs. The lipases present in these pastes produce characteristic tastes.

The aim of this research was to evaluate the use of lamb rennet paste in a Spanish goat cheese (Murcia al Vino cheese) to obtain new artisanal cheeses different from those obtained with calf rennet. The evaluation is based on the study of differences in the lipolytic and sensory patterns at different ripening stages. 


\section{MATERIALS AND METHODS}

\section{Experimental Design}

A randomized factorial design with 2 factors and 2 replications was used to study the effect of the different rennets (liquid calf rennet and an experimental lamb paste rennet). The liquid rennet was considered as a control. Three cheese ripening times $(2,45$, and $60 \mathrm{~d}$ ) were investigated. The cheeses obtained were analyzed to assess their FA profile and sensory properties.

\section{Artisanal Lamb Rennet Paste}

Only whitish abomasa from lambs killed with a full stomach were selected for the manufacture of lamb rennet paste, in which 1-mo-old lambs were selected (The Cistérniga, Valladolid; www.cuajoscaporal.com). The full abomasa were kept refrigerated at 4 to $6^{\circ} \mathrm{C}$ in brine up to a maximum of $7 \mathrm{~d}$. Then the abomasa were grounding with a $23 \%$ of $\mathrm{NaCl}$.

To characterize this rennet, the following parameters were determined: chymosin $(71.1 \%)$, total milk-clotting activity [177 international milk-clotting units (IMCU)/ $\mathrm{mL}$ ] and lipase activity $(4.6 \mathrm{U} / \mathrm{g}$ ) as described by Ferrandini et al. (2008). Before the addition of rennet to the milk, $60 \mathrm{~g}$ of rennet paste was mixed with $100 \mathrm{~mL}$ of distilled water and filtered using a thin cloth to obtain an aqueous extract. The lamb rennet paste extract was added to milk at a concentration of $0.20 \mathrm{~mL} / \mathrm{kg}$ of milk.

\section{Commercial Liquid Rennet}

The enzymatic composition and milk-clotting activity of liquid animal rennet were provided by Caglio Star S.A. (Cieza, Murcia, Spain). The sample had $80 \%$ chymosin and a total milk-clotting activity of $180 \mathrm{IMCU} /$ $\mathrm{mL}$. The calf rennet was added at a concentration of $0.14 \mathrm{~mL} / \mathrm{kg}$ milk.

\section{Murciano-Granadina Goat Milk}

The mean values of the different physicochemical parameters were: $\mathrm{pH}(6.60 \pm 0.00), \mathrm{DM}(13.30 \% \pm 0.02)$, fat $(4.98 \% \pm 0.03)$, and protein $(3.43 \% \pm 0.04)$, as was described by Ferrandini et al. (2011).

\section{Experimental Murcia al Vino Cheese}

The cheeses were produced on $2 \mathrm{~d}$ at the University of Murcia Food Technology Pilot Plant with $1 \mathrm{~d}$ in between. A total of 4 cheeses were made with each type of rennet (lamb and calf) on both days. A 5-L double-
O, stainless steel cheese vat (AISI-310; Cameselle SL, Vigo, Spain) was used for cheese manufacture.

Murciana-Granadina pasteurized goat milk was tempered up to a constant temperature of 30 to $34^{\circ} \mathrm{C}$. Stirring slowly, $\mathrm{CaCl}_{2}$ and rennet were added. After cutting, 2 series of stirring $(5 \mathrm{~min}$ ) and pitching $(5 \mathrm{~min})$ were carried out, followed by a washing and heating step $\left(38^{\circ} \mathrm{C}\right)$, and final stirring. The curd was then molded, pressed, salted, bathed with red wine, and ripened.

The exact rennet dose could be calculated, as the total milk clotting activity of each rennet was known. Preliminary tests were used to select enzyme concentrations, whereas the concentrations of both rennets were selected to obtain a curd cutting time of $40 \pm 5 \mathrm{~min}$. All cheese manufacturing processes were performed with the collaboration of an accredited expert cheesemaker and under the supervision of a representative member of the board of protected designation of origin (PDO) Murcia al Vino cheese to ensure that the manufacturing process used followed the standard procedure for Murcia al Vino cheese. Before sampling, the cheese rind was discarded and the cheeses were grated and kept in airtight plastic containers at $-80^{\circ} \mathrm{C}$ until the analyses were performed. The physicochemical characterization of cheese samples is that described by Ferrandini et al. (2011).

\section{Total FA}

To determine the total FA (TFA) composition of cheese samples, lipid extraction was performed before derivatization, identification, and quantification by GC (ISO, 1996), using a GC8000 series gas chromatograph (Fisons Instruments SpA, Milano, Italy) equipped a with flame ionization detector (FID-80). A capillary column with $5 \%$ crosslinked phenyl methyl siloxane, 30 $\mathrm{m}$ long, 0.25-mm i.d., and 0.25- $\mu \mathrm{m}$ film thickness (HP5; Hewlett-Packard, Barcelona, Spain), was used. The methyl esters were quantified using the methyl esters of undecanoic acid (Sigma U 0250; Sigma-Aldrich Quimica SA, Madrid, Spain) as internal standard and from the calibration curves for each FA. Triplicate injections of each sample were made.

\section{FFA}

Gas liquid chromatographic analysis of each cheese sample was made in duplicate. Underivatized FFA were quantified by GLC on a Hewlett-Packard gas chromatograph (model 5890 series II) on a fused-silica capillary column $(25 \mathrm{~m} \times 0.32 \mathrm{~mm})$ coated with FFA phase (crosslinked polyethylene glycol, $0.52-\mu \mathrm{m}$ layer thickness), as described previously by Chávarri et al. 
(1997). Quantification was carried out with pentanoic, nonanoic, and heptadecanoic acids (Sigma-Aldrich Quimica SA) as internal standards added to the cheese sample at the time of extraction.

\section{Sensory Analysis}

A sensory analysis was performed to determine the existence of significant differences between calf and rennet paste cheese at 2 ripening days ( 45 and $60 \mathrm{~d}$ ) by a panel of expert assessors who were members of the regulatory PDO Murcia al Vino cheese council. The panel was composed of an average of 10 panelists, the number of panelists never being below 8 . The samples were served monadically to each panelist. Each cheese was split into 2 parts, which were labeled using different numbers of randomly chosen digits. One was divided into wedges of approximately 1-cm thickness after the rind was removed. The other whole half was used for the visual phase. The descriptive sensory analysis used the same scoring system as used by the PDO of Murcia al Vino cheese. This score set included 8 descriptors (Table 1), with a structured intensity scale ranging between 1 and 9 , and each attribute was multiplied by a coefficient determined from the contribution of each attribute to the overall perception (Table 1). Unsalted crackers, green apples, and mineral water were served to remove any aftertaste between samples.

\section{Statistical Methods}

The data were analyzed using the general linear model (GLM) procedure of the variable/multivariable Statistix for Windows (7.0 and 8.0; Analytical Software, Tallahassee, FL). An ANOVA test was carried out to compare lamb rennet paste and calf liquid rennet cheeses.

\section{RESULTS AND DISCUSSION}

\section{Total FA Profile}

The evolution of TFA in both types of cheese during ripening is detailed in Table 2. No significant differences were determined between them during the study. Little information on the TFA of goat cheese is reported in the references consulted. However, in Rocamadour goat cheese, Lucas et al. (2008) found lower levels of shortchain $\left(2.92,3.35,10.50\right.$, and $4.74 \%$ for $\mathrm{C}_{6}, \mathrm{C}_{8}, \mathrm{C}_{10}$, and $\mathrm{C}_{12}$, respectively), similar levels of medium-chain $\left(\mathrm{C}_{14}\right.$, $\mathrm{C}_{16}$ ), and higher levels of long-chain $(17.2,2.25$, and $0.73 \%$ for $\mathrm{C}_{18: 1}, \mathrm{C}_{18: 2}$, and $\mathrm{C}_{18: 3}$ ) FA than those found in this study, although the ripening period was not specified. These differences between the respective findings of this study and the above could be related with the higher percentage of lipases contained in the rennet paste used by those authors (Lucas et al., 2008).

Table 3 shows the percentage values of the TFA grouped according to the degree of saturation. No statistical differences were observed between the commercial and paste rennet cheeses with regard to the saturation and length of the carbon chain groups. As can be seen, the total SFA levels of the cheeses made with calf rennet increased toward the end of ripening, whereas they began to fall after $45 \mathrm{~d}$ in the cheeses made with lamb rennet paste. This decrease contrasts with the observations of Pirisi et al. (2007), who observed an increase in SFA at $60 \mathrm{~d}$, although the rennet used (lamb rennet paste in Fiore Sardo cheese) showed less coagulating activity (143 IMCU/mL). The highest levels were recorded at $60 \mathrm{~d}(88.32 \%)$ in calf rennet cheeses and the lowest in the same cheeses at $45 \mathrm{~d}$. Aro et al. (1998) found lower values (62.51\%) of saturated acids in Spanish cheeses than those determined in this study.

Table 1. Specifications for evaluating the different cheese sensory attributes considered

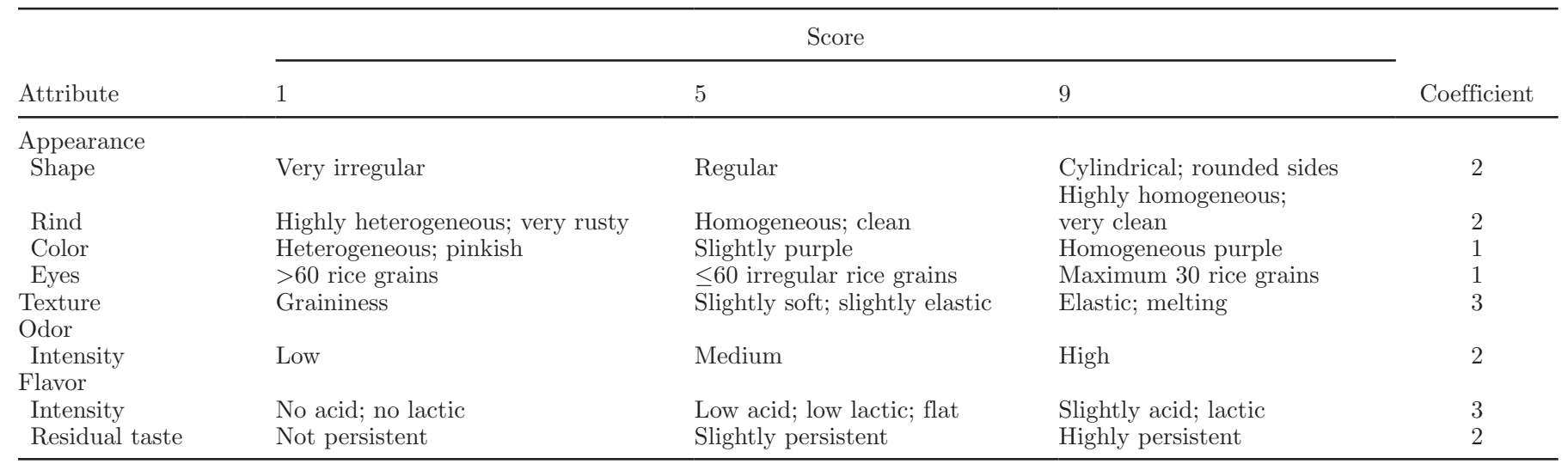


Table 2. Levels (mean $\pm \mathrm{SD}, \%$ ) of total $\mathrm{FA} \mathrm{C}_{6}$ to $\mathrm{C}_{16}$ of different cheeses during ripening (d)

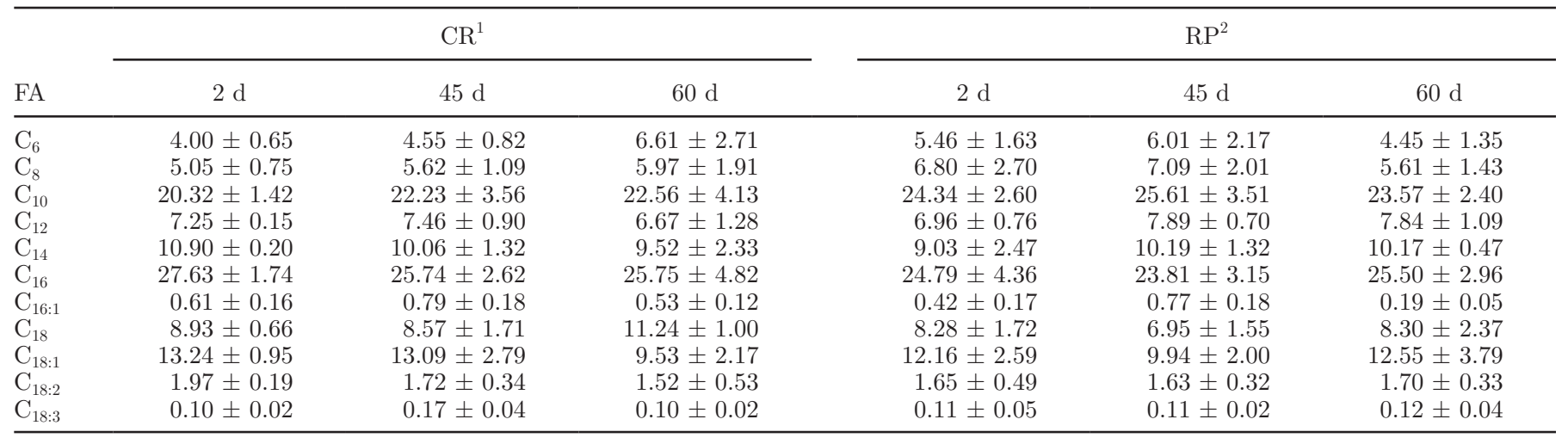

${ }^{1}$ Calf liquid rennet.

${ }^{2}$ Lamb rennet paste.

The levels of total MUFA $\left(\mathrm{C}_{16: 1}\right.$ and $\left.\mathrm{C}_{18: 1}\right)$ in the commercial rennet cheeses reached $13.87 \%$ at $45 \mathrm{~d}$ and then fell to $10.06 \%$ by $\mathrm{d} 60$. In the cheeses made with rennet paste, the MUFA value had decreased by $45 \mathrm{~d}$ but increased toward the end of ripening in agreement with Pirisi et al. (2007), who observed an increase in both MUFA and PUFA in Fiore Sardo cheese made with lamb rennet paste after $60 \mathrm{~d}$ of ripening. The levels of PUFA determined $\left(\mathrm{C}_{18: 2}\right.$ and $\left.\mathrm{C}_{18: 3}\right)$ decreased with time in the commercial rennet cheeses but remained constant in the cheeses made with rennet paste.

Total FA grouped according to the length of the carbon chain are shown in Table 3. Hernández et al. (2005) concluded that the increase in total lipolysis is related with an increase in the level of short-chain FA. As can be observed, the short-chain FA content increases during ripening in both types of cheeses, except in rennet paste cheeses at $60 \mathrm{~d}$ of ripening that showed lower short-chain FA percentages. The same authors also concluded that the lamb rennet paste lipolytic pattern was related to the high pregastric lipase content of the rennet. Nevertheless, we observed no significant differ- ences between the 2 types of cheese at any ripening time.

Soryal et al. (2004) found lower values for short-chain FA in a fresh Domiati cheese made from goat milk and commercial rennet than we found in either cheese type. The same authors also found lower levels of long-chain FA at the beginning of ripening. da Silva Boavida Canada (2001) suggested that the TFA composition of cheese does not change during ripening, with the exception of short-chain $\mathrm{FA}\left(\mathrm{C}_{4}-\mathrm{C}_{10}\right)$ in cheeses with a higher degree of lipolysis, which agrees with our findings. With regard to the long- and medium-chain FA contents, no significant differences were observed between cheeses, in disagreement with Addis et al. (2008) who found lower percentages of both long- and medium-chain FA when comparing cheeses made with lamb rennet paste.

\section{FFA Profile}

The following FFA were not detected in either of the cheeses analyzed: isobutyric $\left(\mathrm{iC}_{4}\right)$, valeric $\left(\mathrm{C}_{5}\right)$, isovaleric $\left(\mathrm{iC}_{5}\right)$, isocaproic $\left(\mathrm{iC}_{6}\right)$, enanthic $\left(\mathrm{C}_{7}\right)$, nonanoic $\left(\mathrm{C}_{9}\right)$,

Table 3. Total FA content ${ }^{1}$ (mean $\pm \mathrm{SD}$ ) as a function of saturation (\%) and length of carbon chain (\%) in cheeses

\begin{tabular}{|c|c|c|c|c|c|c|}
\hline \multirow[b]{2}{*}{ FA } & \multicolumn{3}{|c|}{$\mathrm{CR}^{2}$} & \multicolumn{3}{|c|}{$\mathrm{RP}^{3}$} \\
\hline & $2 \mathrm{~d}$ & $45 \mathrm{~d}$ & $60 \mathrm{~d}$ & $2 \mathrm{~d}$ & $45 \mathrm{~d}$ & $60 \mathrm{~d}$ \\
\hline SFA & $84.08 \pm 0.66$ & $84.23 \pm 2.88$ & $88.32 \pm 3.97$ & $85.65 \pm 3.39$ & $87.54 \pm 2.21$ & $85.43 \pm 4.45$ \\
\hline MUFA & $13.85 \pm 0.79$ & $13.87 \pm 2.78$ & $10.06 \pm 3.40$ & $12.57 \pm 3.00$ & $10.71 \pm 2.07$ & $12.75 \pm 4.00$ \\
\hline PUFA & $2.06 \pm 0.18$ & $1.82 \pm 0.42$ & $1.61 \pm 0.60$ & $1.76 \pm 0.56$ & $1.75 \pm 0.36$ & $1.81 \pm 0.46$ \\
\hline Short-chain $\mathrm{C}_{6}-\mathrm{C}_{10}$ & $29.37 \pm 2.56$ & $32.40 \pm 5.21$ & $35.13 \pm 8.35$ & $33.51 \pm 9.19$ & $38.72 \pm 7.59$ & $33.63 \pm 8.40$ \\
\hline Medium-chain $\mathrm{C}_{12}-\mathrm{C}_{14}$ & $18.15 \pm 0.13$ & $17.52 \pm 2.01$ & $16.19 \pm 3.57$ & $15.99 \pm 3.39$ & $18.09 \pm 1.89$ & $18.01 \pm 0.83$ \\
\hline Long-chain $\mathrm{C}_{16}-\mathrm{C}_{18: 3}$ & $52.48 \pm 2.50$ & $50.07 \pm 6.58$ & $45.41 \pm 6.31$ & $50.30 \pm 6.40$ & $43.20 \pm 6.50$ & $48.37 \pm 9.19$ \\
\hline
\end{tabular}

${ }^{1}$ Total content calculated as follows: $\sum_{i=1}^{n}\left(\bar{X}_{1}+\bar{X}_{2}+\ldots+\bar{X}_{n}\right)$, where $\bar{X}$ is the mean of each FA.

${ }^{2}$ Calf liquid rennet.

${ }^{3}$ Lamb rennet paste. 
Table 4. Levels (mean $\pm \mathrm{SD}$ ) of FFA $\mathrm{C}_{2}$ to $\mathrm{C}_{18}$ ( $\mu \mathrm{mol} / \mathrm{kg}$ of cheese) in cheeses during ripening (d)

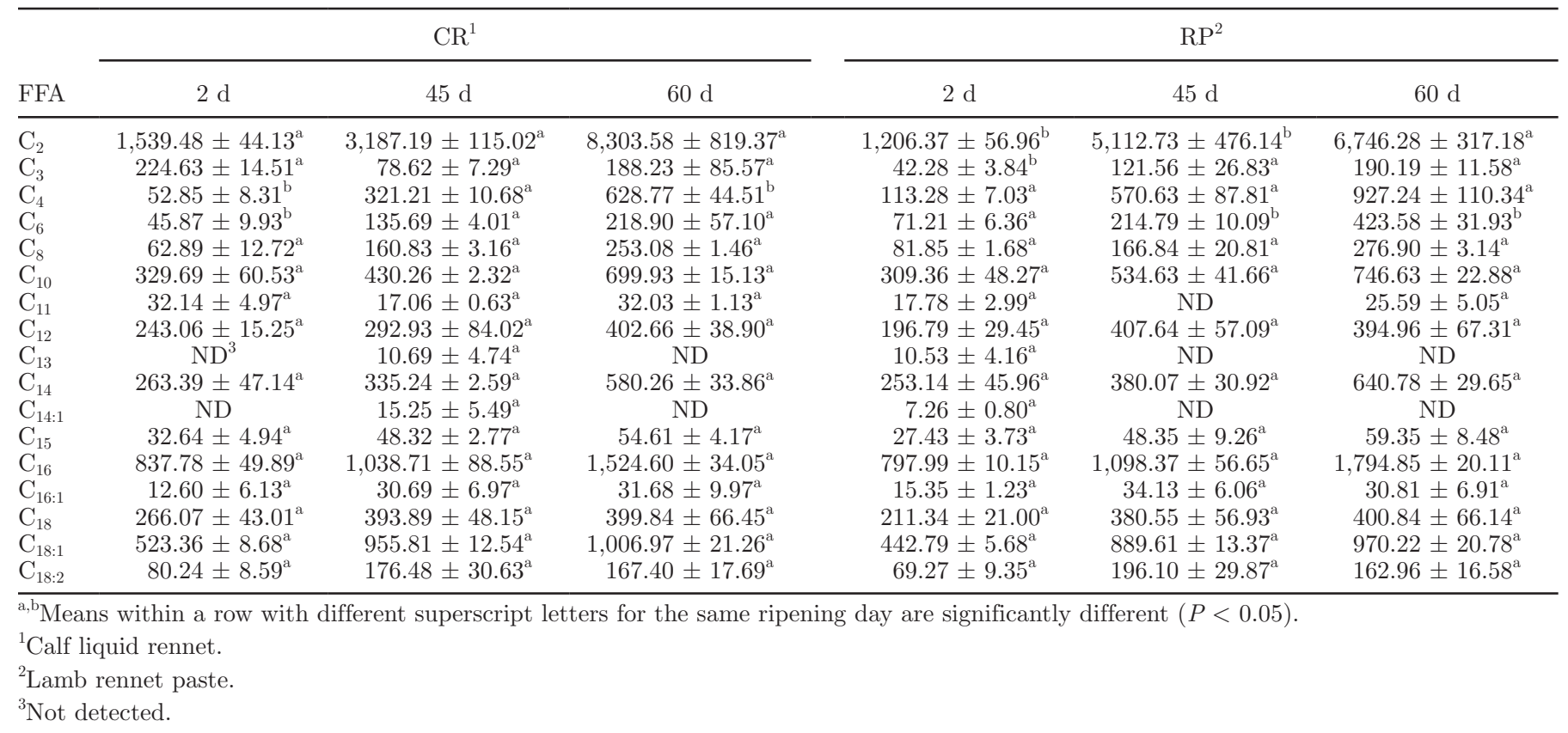

margaric $\left(\mathrm{C}_{17}\right)$, $\alpha$-linoleic $\left(\mathrm{C}_{18: 3}\right)$, nonadecanoic $\left(\mathrm{C}_{19}\right)$, and arachidic $\left(\mathrm{C}_{20}\right)$. The FFA determined in this study at 2, 45, and $60 \mathrm{~d}$ are shown in Table 4 .

No significant differences were detected between the cheese types with regard to the levels of $\mathrm{C}_{2}$ measured at the last ripening time or for $\mathrm{C}_{3}$ at the last 2 ripening times. At the beginning of ripening, the values were significantly lower in the rennet paste cheeses $(P<0.05)$. The highest value of $\mathrm{C}_{2}$ was determined in the commercial rennet cheese at $60 \mathrm{~d}$, whereas the highest concentration of $\mathrm{C}_{3}$ was measured in the commercial rennet cheese at $2 \mathrm{~d}$ and the lowest in rennet paste cheese at the same time. Yilmaz et al. (2005) showed that the $\mathrm{C}_{2}$ content in Tulum cow milk cheese was highest at the beginning of ripening, in contrast with our findings in goat milk cheeses. The same authors affirm that $\mathrm{C}_{2}$ and $\mathrm{C}_{3}$ in cheese are produced as a consequence of lactose fermentation by bacterial action (acetic glycolysis) and the decarboxylation and oxidative deamination of AA, and not as a result of lipolysis. Georgala et al. (2005) found a 3.6 times higher value in mixed sheep-goat Feta cheese after $60 \mathrm{~d}$, which is similar to that found in the current study and by Virto et al. (2003) after $90 \mathrm{~d}$ in ewe cheese.

The $\mathrm{C}_{4}$ values determined differed significantly between the 2 types of cheese except at $45 \mathrm{~d}$ of ripening. The higher levels found in the rennet paste cheeses throughout ripening confirm the higher lipolytic activity of the paste. Significant differences were observed in the caproic acid $\left(\mathrm{C}_{6}\right)$ concentration between both types of cheese throughout the ripening period, the concentration being higher in the rennet paste cheeses.

No significant differences were observed in the levels of $\mathrm{C}_{8}$ and $\mathrm{C}_{10}$. Lamb rennet paste cheeses showed higher values, especially in the rennet paste cheese at $60 \mathrm{~d}$. At 2 and $60 \mathrm{~d}$, the highest $\mathrm{C}_{11}$ values were found in the cheeses made with calf rennet, whereas at $45 \mathrm{~d}$, this FA was not detected in lamb rennet paste cheeses. In general, the levels of $\mathrm{C}_{11}$ are not mentioned in the literature.

The levels of $\mathrm{C}_{12}$ and $\mathrm{C}_{18: 2}$ showed similar behavior, with no significant differences between the cheeses, although the highest value at the beginning of ripening corresponded to the cheeses made with commercial rennet. In addition, $\mathrm{C}_{13}$ was not detected in cheeses made with rennet paste at $45 \mathrm{~d}$ in cheeses made with calf rennet at $2 \mathrm{~d}$ and at $60 \mathrm{~d}$ of ripening in any type of cheese. In the case of $\mathrm{C}_{14}, \mathrm{C}_{15}$, and $\mathrm{C}_{16}$, the highest values were observed in the commercial rennet cheeses at $2 \mathrm{~d}$, whereas at 45 and $60 \mathrm{~d}$, the highest values were found in rennet paste cheeses.

As can be seen from Table $4, \mathrm{C}_{14: 1}$ was not detected in the calf rennet cheeses at the beginning or end of ripening, or in the rennet paste cheeses at $45 \mathrm{~d}$. The highest concentration was observed in the cheeses made with calf rennet at $45 \mathrm{~d}$ of ripening.

The $\mathrm{C}_{16: 1}$ concentrations were low in all of the cheeses compared with the values of the other FFA, the highest level being found in cheeses made with rennet paste at $45 \mathrm{~d}$. No significant differences were found for $\mathrm{C}_{18}$. The 
maximum value was recorded in the cheeses at $60 \mathrm{~d}$ and the minimum in the cheeses made with rennet paste at the beginning of ripening.

Oleic acid, along with palmitic acid, showed one of the highest concentrations of all of the FFA recorded in the cheeses under study. Its concentration rose throughout the ripening period, with no significant differences between cheeses. The highest values were found in cheeses made with calf rennet at the end of ripening and the lowest values in rennet paste cheeses at the beginning of the process.

No significant differences were determined in $\mathrm{C}_{18: 2}$ between the cheeses at any time. Values increased in both types of cheese from the beginning of ripening until the middle, whereas they fell slightly at the end (Table 4).

Franco et al. (2003) found higher FFA concentrations of $\mathrm{C}_{4}, \mathrm{C}_{6}, \mathrm{C}_{8}, \mathrm{C}_{10}, \mathrm{C}_{12}, \mathrm{C}_{14}, \mathrm{C}_{18}, \mathrm{C}_{18: 1}, \mathrm{C}_{18: 2}$, and $\mathrm{C}_{18: 3}$ in Babia-Laciana goat cheese at $3 \mathrm{~d}$ due to its high milk fat content and Poveda and Cabezas (2006) found a higher level of $\mathrm{C}_{12}$ in a different Spanish goat cheese. Higher levels of $\mathrm{C}_{18: 1}$ and $\mathrm{C}_{18: 3}$ were found in Caciocavallo-Pugliese and Majorero cheese by Gobbetti et al. (2002) and Fontecha et al. (1990), respectively; both authors related this increase to the coagulation process. In addition, higher values of $\mathrm{C}_{4}, \mathrm{C}_{6}, \mathrm{C}_{10}, \mathrm{C}_{14}$, $\mathrm{C}_{18}$, and $\mathrm{C}_{18: 2}$ were recorded in 45-d-old semi-hard goat cheese made with kid rennet by Fontecha et al. (2006).

Similar concentrations of $\mathrm{C}_{6}$ and $\mathrm{C}_{18}$ were found by Mallatou et al. (2003) and of $\mathrm{C}_{10}$ by Poveda and Cabezas (2006) in Teleme and Spanish cheeses, respectively, at $60 \mathrm{~d}$. Higher values of $\mathrm{C}_{4}, \mathrm{C}_{6}, \mathrm{C}_{8}, \mathrm{C}_{10}, \mathrm{C}_{12}, \mathrm{C}_{14}, \mathrm{C}_{18}$, were found by Franco et al. (2003) in Babia-Laciana cheese, Fontecha et al. (1990) in Majorero cheese, and Georgala et al. (2005) in mixed goat-sheep milk Feta cheese. Higher values of $\mathrm{C}_{18: 1}$ and $\mathrm{C}_{18: 2}$ were recorded by Franco et al. (2003) and Georgala et al. (2005) in the aforementioned cheese; also, higher values of $\mathrm{C}_{18: 3}$ were found by Franco et al. (2003). Poveda and Cabezas (2006) also found higher values of $\mathrm{C}_{6}, \mathrm{C}_{10}, \mathrm{C}_{14}, \mathrm{C}_{18}$, and $\mathrm{C}_{18: 1}$ in Spanish goat cheeses, Mallatou et al. (2003) found higher values of $\mathrm{C}_{8}$ and $\mathrm{C}_{18: 2}$ in Teleme goat cheese, and Freitas and Malcata (1996) found higher values of $\mathrm{C}_{10}$ in mixed goat-sheep milk Picante cheese. In contrast, other authors found lower concentrations of several FFA at 60 d: Mallatou et al. (2003) in Teleme goat cheese in the case of $\mathrm{C}_{4}, \mathrm{C}_{10}, \mathrm{C}_{12}, \mathrm{C}_{14}$, and $\mathrm{C}_{18: 1}$ and Poveda and Cabezas (2006) in Spanish goat cheeses for $\mathrm{C}_{8}$.

From the above observations, it can be concluded that lamb rennet paste has a significantly stronger lipolytic effect (especially on the short-chain FA) than calf rennet when used in Murcia al Vino cheese. The FFA can be classified according to the length of the chain, as shown in Table 5. The short-chain FFA correspond to VFA and had a significantly higher value in cheeses made with lamb rennet paste. No significant differences in medium-chain FFA were observed, although the values were lower in the cheese made with lamb paste rennet. With regard to long-chain FFA, although no significant differences were found at the beginning, significantly lower values were determined at 45 and 60 $\mathrm{d}$ in rennet paste cheeses.

If we compare the FFA values (Table 4) of each group separately and for the same type of rennet, the behavior in both cheeses is similar, with short-chain FFA increasing and mid-length and long-chain FFA decreasing as ripening progresses. The short-chain FFA correspond to VFA and showed percentage values significantly higher in cheeses made with lamb rennet paste, in agreement with Virto et al. (2003) in Idiazábal cheese using the same rennet paste.

Our results can be compared with those published by De Renobales et al. (2005), who used the lamb rennet paste to make Idiazábal, Zamorano, and Manchego cheeses. In our case, the short-chain FFA had increased by $7.5 \%$ at $60 \mathrm{~d}$, which is less than the $19 \%$ recorded at $180 \mathrm{~d}$ in Manchego and Idiazábal (27\%) cheeses and at $240 \mathrm{~d}$ in Zamorano cheese (19\%). The long-chain FA decreased by $6.38 \%$ at $60 \mathrm{~d}$ in Murcia al Vino cheese, whereas Manchego, Idiazábal, and Zamorano cheeses showed more pronounced decreases $(17,21$, and $15 \%$, respectively). The lipolytic activity was higher in cheeses matured for longer times, such as Idiazábal cheese, than in cheeses with a short ripening period.

\section{Sensory Analysis}

The statistical study of the scores obtained for each sensory attribute is reflected in Table 6 . It can be seen that the type of rennet does not significantly affect shape, rind, or color at 45 or $60 \mathrm{~d}$.

With regard to the number of eyes, significant differences $(P<0.01)$ between the cheese types were observed at both 45 and $60 \mathrm{~d}$. The lower score obtained by the rennet paste cheese reflects the greater number of holes in this cheese; this may be due to the different textural properties of the cheese made with lamb rennet paste, as was previously reported by Ferrandini et al. (2011). These authors found that rennet paste cheeses were harder, less deformable and, therefore, less accepted than those made with commercial liquid rennet.

Significant differences also existed at $45(P<0.05)$ and $60(P<0.01) \mathrm{d}$ for the texture appreciation scores, cheeses made with rennet paste being judged firmer than the cheeses made with commercial rennet. Significant differences were noted for odor intensity at $45 \mathrm{~d}$ but not at the last ripening time. 
Table 5. Free FA content ${ }^{1}$ (mean $\left.\pm \mathrm{SD} ; \%\right)$ in cheese according to chain length

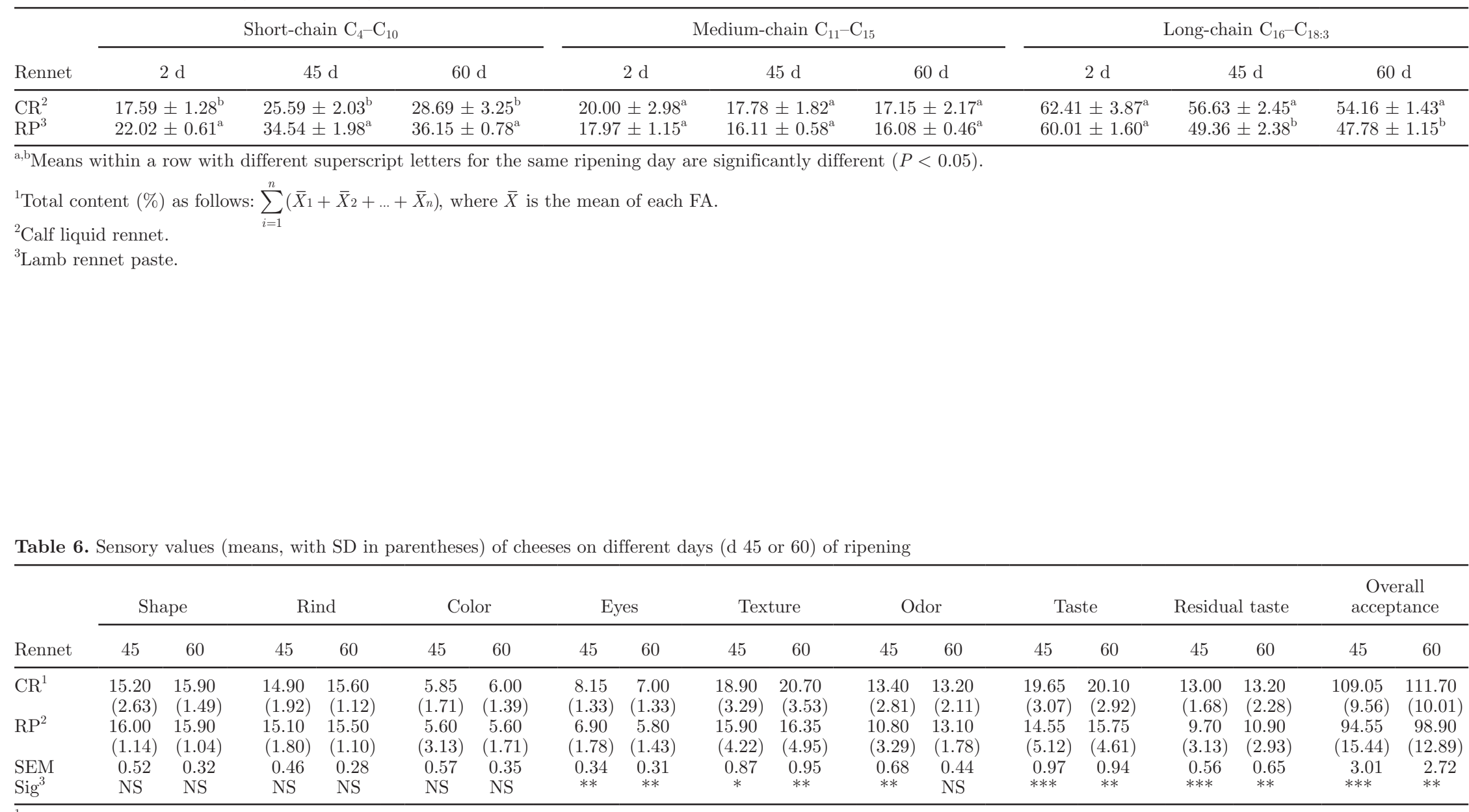

${ }^{1}$ Calf liquid rennet.

${ }^{2}$ Lamb rennet paste.

${ }^{3} \mathrm{Sig}=$ significance level.

*** $P<0.001 ;{ }^{* *} P<0.01 ; * P<0.05$ 
Highly significant statistical differences in flavor (99.9 and $99.0 \%$, respectively) were observed between the 2 types of cheese at 45 and $60 \mathrm{~d}$, those made with rennet paste having a slightly more bitter and piquant taste and, thus, obtaining a lower overall score. These statistically significant differences in flavor between cheeses made with lamb rennet paste and commercial rennet are related to the short-chain FA content. As reported by Hernández et al. (2005), the percentage of short-chain FA is closely correlated with the score for the attribute pungent flavor, and other authors, such as Virto et al. (2003), Bustamante et al. (2000), and Bustamante (2002), related the content of this FA group in lamb rennet paste cheeses to strong attributes such as sharp odor and piquant taste. As is shown in Table 4, lamb rennet paste cheeses showed a higher content of short-chain FFA than commercial rennet cheeses, which agrees with the authors mentioned above. The fact that the paste and commercial rennet cheeses showed significant differences in odor intensity at $45 \mathrm{~d}$, but not at $60 \mathrm{~d}$, could be related to the significant differences observed in the $\mathrm{C}_{2} \mathrm{FFA}$ content of the 45-d-old cheese. Such a difference was not observed in the 60-d-old cheeses, whereas the differences in the $\mathrm{C}_{4}$ FFA content observed in 60-d-old cheese were not observed in the $45 \mathrm{~d}$-old cheese.

The overall score for the cheese was taken as the sum of all of the partial qualifications of the parameters studied (Table 1). The cheeses made with commercial rennet obtained higher scores at both 45 and $60 \mathrm{~d}$.

The PDO qualification of Murcia al Vino cheese also depends on the total score values of 136 to 144 being considered excellent, 110 to 135 very good, 96 to 109 acceptable, 76 to 95 poor, and 50 to 75 deficient. At 60 $\mathrm{d}$, the lamb rennet paste cheese fell within the limits established by PDO Regulatory Council for retail and consumption $(>75)$. This lower overall acceptance may have been related with the slightly bitter and piquant taste commonly perceived in the cheeses made with lamb rennet paste, as mentioned by Bustamante (2002) for Idiazábal cheese made with the same lamb rennet paste. Such a bitter and piquant taste is related to the greater lipolytic activity and release of short-chain FFA, especially butyric acid. The rennet paste provides lipolytic enzymes to the milk, especially pregastric lipase, which shows maximum activity close to a $\mathrm{pH}$ of approximately 5.5 (normal pH of cheese after pressing) and is responsible for the piquant taste (due to its sterasic action on the triglycerides in the milk) as a consequence of the release of FA.

All of the judges mentioned the difference in flavor of the cheese made with lamb paste rennet compared with the normal one, which could be considered an interest- ing opportunity for diversifying the offer of goat cheeses from the province of Murcia.

\section{CONCLUSIONS}

Based on the above results, it can be concluded that use of lamb paste rennet to make Murcia al Vino cheese does not influence the TFA composition profile, although it does influence the short-chain FFA profile and overall acceptance. The use of lamb rennet paste leads to higher lipolytic activity and its effect on the hydrolysis of triglycerides to short-chain FA is also more pronounced. Taking into account the importance of lipolysis in flavor development in some cheese varieties, the use of rennet paste may lead to improvements in cheese quality by increasing the enzymatic hydrolysis of triacylglycerides. The differences in the overall acceptance and the perception of new flavors in the lamb rennet paste cheeses confirm the experimental rennet paste developed for the manufacture of Murcia al Vino cheese as an interesting commercial alternative for the goat cheesemaking sector in Spain.

\section{ACKNOWLEDGMENTS}

The authors acknowledge the economic support of the Spanish Ministry of Science and Technology (Madrid, Spain) through Project no. AGL2000-1029-C03-02 and the invaluable collaboration of Cuajos Caporal (La Cistérniga, Valladolid, Spain).

\section{REFERENCES}

Addis, M., G. Piredda, and A. Pirisi. 2008. The use of lamb rennet paste in traditional sheep milk cheese production. Small Rumin. Res. 79:2-10.

Aro, A., J. M. Antoine, L. Pizzoferrato, O. Reykdal, and G. van Poppel. 1998. Transfatty acids in dairy and meat products from 14 European countries: The TRANSFAIR Study. J. Food Compost. Anal. 11:150-160.

Bustamante, M., F. Chávarri, A. Santisteban, G. Ceballos, I. Hernández, M. J. Miguélez, I. Aranburu, L. J. R. Barrón, M. Virto, and M. de Renobales. 2000. Coagulating and lipolytic activities of artisanal lamb rennet pastes. J. Dairy Res. 67:393-402.

Bustamante, M. A. 2002. El cuajo de cordero en pasta: Preparación y efecto en los procesos proteolíticos y lipolíticos de la maduración del Queso Idiazabal. PhD Thesis. Universidad del País Vasco, Vitoria-Gasteiz, Spain.

Chávarri, F., M. Virto, C. Martín, A. I. Nájera, A. Santisteban, L. J. R. Barrón, and M. De Renobales. 1997. Determination of free fatty acids in cheese: Comparison of two analytical methods. J. Dairy Res. 64:445-452.

Collins, Y. F., P. L. H. Mc Sweeney, and M. G. Wilkinson. 2003. Lipolysis and free fatty acid catabolism in cheese: A review of current knowledge. Int. Dairy J. 13:841-866.

da Silva Boavida Canada, J. 2001. Caracterización sensorial y físicoquímica del Queijo Serpa. PhD Thesis. Universidad de Extremadura, Cáceres, Spain.

de Renobales, M., J. Laencina, E. Ferrandini, M. B. López, M. Virto, M. Albisu, F. J. Perez Elortondo, L. J. R. Barrón, A. I. Nájera, 
A. Guerra, and C. Delgado. 2005. Characterization of lamb rennet paste and optimization of processing methods to recover traditional flavours in sheep and goat milk cheeses. Pages 261-262 in Special Issue: Future of the Sheep and Goats Dairy Sector. Part 4: Features and Technological Aptitudes of Sheep and Goat Milks: New Technologies. Int. Dairy Fed., Brussels, Belgium.

Ferrandini, E., M. B. López, M. Castillo, M. De Renobales, M. Virto, I. Hernández, A. V. Price, and J. Laencina. 2008. Technological characterization of experimental natural rennet pastes. Food Sci. Technol. Int. 14:63-70.

Ferrandini, E., M. B. López, M. Castillo, and J. Laencina. 2011. Influence of an artisanal lamb rennet paste on proteolysis and textural properties of Murcia al Vino cheese. Food Chem. 124:583-588.

Fontecha, J., I. Castillo, L. Blasco, L. Alonso, and M. Juárez. 2006. Effect of artisanal kid rennet paste on lipolysis in semi-hard goat cheese. Food Chem. 98:253-259.

Fontecha, J., C. Peláez, M. Juárez, T. Requena, and C. Gómez. 1990. Biochemical and microbiological characteristics of artisanal hard goat's cheese. J. Dairy Sci. 73:1150-1157.

Franco, I., B. Prieto, A. Bernardo, J. González Prieto, and J. Carballo. 2003. Biochemical changes throughout the ripening of a traditional Spanish goat cheese variety (Babia-Laciana). Int. Dairy J. $13: 221-230$.

Freitas, A. C., and F. X. Malcata. 1996. Influence of milk type, coagulant, salting procedure and ripening time on the final characteristics of Picante cheese. Int. Dairy J. 6:1099-1116.

Georgala, A., E. Moschopoulou, A. Aktypis, T. Massouras, E. Zoidou, I. Kandarakis, and E. Anifantakis. 2005. Evolution of lipolysis during the ripening of traditional Feta cheese. Food Chem. 93:73-80.

Gobbetti, M., M. Morea, F. Baruzzi, M. R. Corbo, A. Matarante, T. Considine, R. Di Cagno, T. Guinee, and P. F. Fox. 2002. Microbiological, compositional, biochemical and textural characterisation of Caciocavallo Pugliese cheese during ripening. Int. Dairy J. $12: 511-523$.

Harboe, M. K. 1994. Use of lipases in cheesemaking. Pages 11-16 in The use of lipases in cheesemaking. International Dairy Federation, Brussels, Belgium.
Hernández, I., M. D. Renobales, M. Virto, F. J. Pérez-Elortondo, L. J. R. Barron, C. Flanagan, and M. Albisu. 2005. Assessment of industrial lipases for flavour development in commercial Idiazabal (ewe's raw milk) cheese. Enzyme Microb. Technol. 36:870-879.

ISO (International Organization for Standardization). 1996. Aceites y grasas de origen animal y vegetal. Análisis por cromatografía en fase gaseosa de los ésteres metílicos de ácidos grasos (5508:1996). ISO, Geneva, Switzerland.

Lucas, A., E. Rock, C. Agabriel, Y. Chilliard, and J. B. Coulon. 2008. Relationships between animal species (cow versus goat) and some nutritional constituents in raw milk farmhouse cheeses. Small Rumin. Res. 74:243-248.

Mallatou, H., E. Pappa, and T. Massouras. 2003. Changes in free fatty acids during ripening of Teleme cheese made with ewes', goats', cows' or a mixture of ewes' and goats' milk. Int. Dairy J. $13: 211-219$.

McSweeney, P. H. L. 2004. Biochemistry of cheese ripening. Int. J. Dairy Technol. 57:127-144.

Pirisi, A., G. Pinna, M. Addis, G. Piredda, R. Mauriello, S. D. Pascale, S. Caira, G. Mamone, P. Ferranti, F. Addeo, and L. Chianese. 2007. Relationship between the enzymatic composition of lamb rennet paste and proteolytic, lipolytic pattern and texture of PDO Fiore Sardo ovine cheese. Int. Dairy J. 17:143-156.

Poveda, J. M., and M. Cabezas. 2006. Free fatty acid composition of regionally-produced Spanish goat cheese and relationship with sensory characteristics. Food Chem. 95:307-311.

Soryal, K. A., S. S. Zeng, B. R. Min, and S. P. Hart. 2004. Effect of feeding treatments and lactation stages on composition and organoleptic quality of goat milk Domiati cheese. Small Rumin. Res. 52:109-116.

Virto, M., F. Chávarri, M. A. Bustamante, L. J. R. Barron, M. Aramburu, M. S. Vicente, F. J. Pérez-Elortondo, M. Albisu, and M. de Renobales. 2003. Lamb rennet paste in ovine cheese manufacture: Lipolysis and flavour. Int. Dairy J. 13:391-399.

Yilmaz, G., A. Ayar, and N. Akin. 2005. The effect of microbial lipase on the lipolysis during the ripening of Tulum cheese. J. Food Eng. 9:269-274. 